\title{
The Analysis of Competitiveness and Economic Growth: A Case Study of Transition Countries
}

\author{
Cevat Gerni ${ }^{1}$, Burhan Kabadayı ${ }^{2}$, Ziya Çağlar Yurttançıkmaz ${ }^{3}$ \& Ömer Selçuk Emsen ${ }^{3}$ \\ ${ }^{1}$ Department of Economics, Beykent University, Istanbul, Turkey \\ ${ }^{2}$ Department of Economics, Erzincan University, Erzincan, Turkey \\ ${ }^{3}$ Department of Economics, Ataturk University, Erzurum, Turkey \\ Correspondence: Burhan Kabaday1, Department of Economics, Erzincan University, Turkey. Tel: \\ 90-535-216-2706. E-mail: burhankabadayi@gmail.com
}

Received: March 4, 2013

Accepted: March 25, 2013

Online Published: April 17, 2013

doi:10.5539/ibr.v6n5p117

URL: http://dx.doi.org/10.5539/ibr.v6n5p117

\begin{abstract}
This study examined the effects of competitiveness on the economic growth of transition countries between the years 1995 and 2009. Panel ARDL (Autoregressive distributed lag) models were applied for 23 countries. The competitiveness of industrial sectors and sub-sectors were calculated by Balassa index, and the effects of the indexes on transition economies (TEs) were checked via the control variables of: capital formation per capita, and globalization index in the Cobb-Douglas production function framework. The findings indicate that some sectors affect TEs positively whereas others affect them negatively.
\end{abstract}

Keywords: transition countries, competitiveness, economic growth, Panel ARDL

\section{Introduction}

Liberal economists propound the advantages of open market economy as being: specialization and economies of scales. By improving economies of scale, countries produce greater output relative to their closed-market potentials. In order to maximize gains from external trade, economies should specialize in sectors or industries that have provide comparative advantages and shift production from industries or sectors that do not provide comparative advantages. Therefore, countries should export goods and services that provide comparative economic advantages, but import goods and services that are comparatively disadvantageous to produce domestically. Within the literature, this structure is termed an export-biased growth model.

The countries referred to as Transition Economies are in the process of transforming their economic, political and socio-cultural structures from centrally planned to liberal and open-market-oriented structures. In particular, transition economies within the former Eastern Bloc did not have leak and uncertainty while planning economic production and consumption. However, with the opening-up of economies - starting in 1991-internal production did not meet internal demand, and demand-shocks led to recession and hyperinflation during the transitional period. Some economies successfully counteracted recession and hyperinflation via political and short-term economic reforms. Conversely, other transition economies experienced long-term recession in parallel with unsuccessful political and economic reforms. In brief, the present study used panel data analysis to analyze the effects of globalization and competitiveness strength of the sectors on economic growths of and the relative influence of sectors on the economic growth of transition countries. KOF indexes were used as globalization indicators and Balassa indexes were used as indicators of competitiveness. A review of the existing literature was conducted prior to empirical analysis.

\section{Competitiveness and Economic Growth}

Developments in national economic structures have positive impacts at the level of international trade, while increasing international trade volume drives economic growth. From this aspect, bilateral causality between economic growth and international trade was on the carpet. However, it is necessary for foreign trade and export volume having exported goods and services diversity and export elasticity to have positive effects on economic growth. It is highly possible that the adoption of more liberal economic policies, combined with dynamism, scale of economies and positive externalities lead to greater economic growth. Therefore, it is expected that production within sectors that have relatively high external demand elasticity would have greater effects on economic 
growth rates. It can be observed that greater elasticity is associated with — but is insufficient to create - greater economic growth. Competitiveness in the related sectors for higher economic growth rates is an important condition. The international competitiveness of a sector can be defined as its relative capacities to generate employment and income relative to that of competitor countries (Demir, 2001: 46).

Competitiveness can be simply defined as the talent of competing with rivals. Competitiveness is examined from the perspective of microeconomics. In other words, competitiveness is to have comparative advantages and sustainable supplying on the operations within free and open international markets. The structure of the comparative advantages is not only created by national resources but also built up by human recourses. In industrial countries, the extent of comparative advantages can be expressed as institutional quality, human capital and the ability to develop "technical knowledge" (Business Council of Australia, 2008: 7-8). Technical knowledge affects the competitiveness in three ways: changing the structure and rules of competition; outperforming rivals through new production methods; and having the potential to create new goods and services (Porter \& Miller, 1985: 2-3). As stated previously, these beneficial effects of competitiveness were defined as a talent. The most important factor of emerging the talents is to integrate competitiveness between the market, operation and culture of firms (Smith, 1995: 42).

Within the literature, the most comprehensive measure of competitiveness is the Institute of Management Development index (IMD). IMD reflects a country's relative competitive strength, and is calculated by taking the average of four factors:

I- Economic performance, including domestic economic performance, level of international trade, international investments, employments and price level.

II- Government efficiency, comprising public finance, public policy, institutional framework, business legislation and social structure.

III- Business Efficiency, reflecting financing, management attitudes and values of the business environment.

IV- Infrastructure, including physical, technological, scientific, health and educational infrastructure (Salvatore, 2010: 25).

Competitiveness was also defined as producing a good or service at relatively lower cost and higher quality than the rest of the world. From this definition, revealed comparative advantages were calculated for national industries and sub-branches of industries. Liesner (1958) firstly mentioned about this event in his article. The application of the Lierner's theoretical predictions was first analyzed by Balassa (1965). From Balassa to Lafay (1992), the literature was dominated by empirical studies. The index shows which economic sectors a country should specialize in.

\section{Literature Review}

From the macroeconomic perspective, a lack of competitiveness can be described as a problem of real exchange rates, and competitiveness can be scaled in terms of price and/or cost indexes, termed common currency. Although some studies use exchange rates and economic growth rates as indicators of competitiveness, these kinds of indicators are inadequate. Rather than exchange rates and economic growth, revealed literatures' works are referred to productiveness, talents and innovations by many scholars. National competitiveness can be explained as productivity. This explanation is also used by the World Bank (Farrugia, 2002: 21-22). However, explanation of competitiveness by price and cost is a short-term event. As Thirlwall (1979) explained, if the income elasticity of exports is high relative to import elasticity, the growth rates of the economies are higher. In the long term, competitiveness includes factors beyond short-term prices and costs, such as talents and innovations. Kaldor (1981: 603) expresses the level of technology and efficiency that can be represented by research and development (R\&D). Fagerberger (1990 and 1994) used export levels as a dependent variable and technology as explanatory variables, combined with control variables of prices-costs, investments and the scales. Technology was represented in the model by the variables of R\&D and trademarks (Soete, 1981) and innovations (Greenhalgh, 1990 and 1994). As a result, it was found that innovations and R\&D had strong positive effects on exports.

In the extended Dornbusch-type Ricardian model, relative terms of export power were examined on the basis of labor. In this framework, the explanatory variables of export power are relative term of labor costs, prices, trade costs and real exchange rates. Nowak-Lehmann et al (2008) compared the Chinese and Mexican economies. The findings show that the advantages of real exchange rates positively affect export power, and that relative terms of labor costs and prices affect export power. On the other hand, changes in the competitiveness of industrial sub-sectors are existing according to the time that reported by Anderson et al. (2000). In the Anderson' study, the 
relationships between competitiveness and efficiencies were analyzed for Sweden's manufacturing industries between the years 1964 and 1996.

Salvatore (2010: 27-29) stressed the relationships between competitiveness and globalization; Salvatore reported a positive correlation between globalization and competitiveness, and found that competitiveness has a relatively strong positive effect on the economic growth rates of countries that have relatively open economies. Although some studies did not examine the direct effect of competitiveness on economic growth, the indirect effects of competitiveness on growth rates were modeled. For example, Dollar and Kraay (2002: 209-219) examined the effects of monetary and fiscal stability, openness and liberal political indicators on the income levels of selected countries. They found positive effects for the rule of law, financial development and international trade volume on the income level, whereas inflation and the size of the public sector within the market had negative effects on income distribution and economic growth.

Ulengin et al (2011) examined the effects of competitiveness on human development. It was found that the most important consequence of competitiveness is a higher level of human development. Sener and Saridogan (2011) used the Global Competitiveness Index to examine the relationship between "science-technology and innovation oriented competitiveness strategy" and long-run economic growth. It was found that countries with relatively high income level have higher competitiveness ratios.

\section{Empirical Work}

The model used in the present empirical analysis is shown in Equation (1):

$$
L G D P P C_{, t}=C+\beta_{1} * L C A P P C_{i, t}+\beta_{2} * L K O F_{i, t}+\beta_{3} * B A L A S S A_{i, t}+u_{i, t}
$$

Where $\mathrm{i}=1, \ldots, 23 ; \mathrm{t}=1995, \ldots, 2009$.

In Equation 1, GDPPC represents GDP per capita; CAPPC is total capital formation per capita. KOF index of globalization was used as the explanatory variable. KOF measures three dimensions of globalization: economic, social and political (http://globalization.kof.ethz.ch/). The index developed by Balassa (1965) represents the comparative advantage of a country's national economic sectors. The Balassa indexes were calculated as shown in Equation (2):

$$
\mathrm{BI}^{\mathrm{A}}=\left(\text { Share of industry } \mathrm{j} \text { in country } \mathrm{A}^{\prime} \text { export }\right) /(\text { share of industry } \mathrm{j} \text { in reference country export })
$$

(Balassa, 1965).

Balassa indexes were calculated for 10 industrial sectors of transitional economies: Food and live animals (FOOD); Beverages and tobacco (BEVE); Crude materials, inedible, except fuels (CRUDE); Mineral fuels, lubricants and related materials (MIN); Animal and vegetable oils, fats and waxes (ANIM); Chemicals and related products, n.e.s. (CHEM); Manufactured goods (MAN); Machinery and transport equipment (MACH); Miscellaneous manufactured articles (MISC); Commodities and transactions, n.e.s (COM).

Data were collected for 23 transition countries for the years 1995 to 2009. The number of cross-sections is 23 and each time series comprises 14 samples for each cross-section. In this analysis, $\mathrm{N}$ is greater than $\mathrm{T}(\mathrm{N}>\mathrm{T})$. Firstly, cross-section dependency was checked was checked via the sum of cross-section dependency tests.

\begin{tabular}{|c|c|c|c|c|c|c|c|c|}
\hline & \multicolumn{2}{|c|}{ Friedman } & \multicolumn{4}{|c|}{ Frees Test } & \multicolumn{2}{|c|}{ Pesaran Test } \\
\hline & Stat & $P$ value & Stat. & $\mathrm{CV} \% 10$ & CV\%5 & $\mathrm{CV} \% 1$ & Stat & P value \\
\hline ANIM & 28.996 & 0.145 & 3.280 & 0.233 & 0.310 & 0.464 & 6.459 & 0.00 \\
\hline BEVE & 27.004 & 0.211 & 3.171 & 0.233 & 0.310 & 0.464 & 6.931 & 0.00 \\
\hline CHEM & 27.802 & 0.182 & 3.411 & 0.233 & 0.310 & 0.464 & 6.185 & 0.00 \\
\hline CRUDE & 25.265 & 0.284 & 2.977 & 0.233 & 0.310 & 0.464 & 6.917 & 0.00 \\
\hline $\mathrm{COM}$ & 29.684 & 0.126 & 3.421 & 0.233 & 0.310 & 0.464 & 6.689 & 0.00 \\
\hline MAN & 29.431 & 0.133 & 3.350 & 0.233 & 0.310 & 0.464 & 6.719 & 0.00 \\
\hline $\mathrm{MACH}$ & 28.466 & 0.160 & 3.164 & 0.233 & 0.310 & 0.464 & 6.547 & 0.00 \\
\hline MIN & 26.316 & 0.238 & 3.966 & 0.233 & 0.310 & 0.464 & 6.073 & 0.00 \\
\hline MISC & 24.150 & 0.339 & 2.903 & 0.233 & 0.310 & 0.464 & 5.586 & 0.00 \\
\hline FOOD & 28.822 & 0.150 & 3.379 & 0.233 & 0.310 & 0.464 & 6.475 & 0.00 \\
\hline
\end{tabular}

Table 1. Cross-section dependency tests 
Based on the results of Friedman and Pesaran tests, the null hypothesis of cross-sectional independence was strongly rejected at the $1 \%$ level of significance for every regression. In the presence of cross-section dependence, second-generation unit root tests were applied. In cases where $\mathrm{N}$ was greater than $\mathrm{T}$, the cross-sectionally augmented Dickey-Fuller test (CADF) was applied (Pesaran, 2006). The estimation results are given at Table 2.

Table 2. Panel unit root tests in the presence of cross-section dependence (CADF)

\begin{tabular}{lllll}
\hline & Constant & & \multicolumn{2}{c}{ Constant and Trend } \\
\cline { 2 - 3 } \cline { 5 - 5 } & T bar & Z bar & T bar & Z bar \\
\hline LGDPPC & $-2.632^{\mathrm{A}}$ & $-4.195^{\mathrm{A}}$ & -2.348 & -0.276 \\
LCAPPC & $-2.179^{\mathrm{B}}$ & $-2.065^{\mathrm{B}}$ & -1.909 & 1.810 \\
LKOF & $-2.149^{\mathrm{B}}$ & $-1.871^{\mathrm{B}}$ & -2.311 & -0.219 \\
ANIM & $-2.406^{\mathrm{A}}$ & -3.132 & $-3.138^{\mathrm{A}}$ & $-4.027^{\mathrm{A}}$ \\
BEVE & $-2.904^{\mathrm{A}}$ & $-5.473^{\mathrm{A}}$ & $-2.881^{\mathrm{A}}$ & $-2.808^{\mathrm{A}}$ \\
CHEM & $-2.040^{\mathrm{C}}$ & $-1.411^{\mathrm{C}}$ & $-2.952^{\mathrm{A}}$ & $-3.143^{\mathrm{A}}$ \\
CRUDE & $-2.800^{\mathrm{A}}$ & $-4.983^{\mathrm{A}}$ & $-3.168^{\mathrm{A}}$ & $-4.170^{\mathrm{A}}$ \\
COM & $-2.855^{\mathrm{A}}$ & $-5.240^{\mathrm{A}}$ & $-3.062^{\mathrm{A}}$ & $-3.667^{\mathrm{A}}$ \\
MAN & -1.981 & -1.132 & -2.442 & -0.720 \\
MACH & $-2.305^{\mathrm{A}}$ & $-2.657^{\mathrm{A}}$ & $-3.131^{\mathrm{A}}$ & $-3.991^{\mathrm{A}}$ \\
MIN & $-2.295^{\mathrm{A}}$ & $-2.611^{\mathrm{A}}$ & $-2.781^{\mathrm{A}}$ & $-2.331^{\mathrm{A}}$ \\
MISC & $-2.359^{\mathrm{A}}$ & $-2.912^{\mathrm{A}}$ & $-3.344^{\mathrm{A}}$ & $-5.004^{\mathrm{A}}$ \\
FOOD & $-2.141^{\mathrm{B}}$ & $-2.294^{\mathrm{B}}$ & $-2.773^{\mathrm{B}}$ & $-2.294^{\mathrm{B}}$ \\
\hline
\end{tabular}

Notes: The critical value (CV) at \%10 is -2.070 ; CV5 is -2.150 ; CV1 is -2.320 with constant. CV10 is -2.580 ; CV5 is -2.670 ; CV10 is -2.830 with contend and trend. A B and $\mathrm{C}$ indicate level of significance at $1 \%, 5 \%$ and $10 \%$.

The CADF unit root test showed that all variables are stationary in the same level. Panel ARDL models were run for each Balassa index, due to having mixed-structure stationary properties.

The panel ARDL model was used, due to having stationary mixed-order variables, and in order to identify long-run relationships between dependent and independent variables. The following model was used, as parameterized by Pesaran, Shin \& Smith (1999).

The ARDL model can be described as:

$$
\begin{gathered}
\triangle L G D P P C_{i t}=\alpha_{i}+\varphi_{i} L G D P P C_{i, t-1}+\delta_{i}{ }^{*} L C A P P C_{i t}+\theta_{i}{ }^{*} L K O F_{i t}++\lambda_{i} * B A L A S S A_{i t} \sum_{j=l}{ }^{p i-1} \beta_{i j} * * \Delta L G D P P C_{i, t-j}+ \\
\sum_{j=0}{ }^{q i} \delta_{i j} * * \Delta L C A P P C_{i, t-j}+\sum_{j=0}{ }^{k i} \theta_{i j} * * \Delta L K O F_{i, t-j}+\sum_{j=0}{ }^{k i} \lambda_{i j} * * \Delta B A L A S S A_{i, t-j}+\varepsilon_{i t}
\end{gathered}
$$

where

$\varphi_{\mathrm{i}}=-\left(1-\Sigma_{\mathrm{j}=1}^{\mathrm{pi}} \beta_{\mathrm{ij}}\right), \delta_{\mathrm{i}}{ }^{*}=\Sigma_{\mathrm{j}=0}^{\mathrm{qi}} \delta_{\mathrm{ij}}, \theta_{\mathrm{i}}{ }^{*}=\Sigma_{\mathrm{j}=0}{ }^{\mathrm{ki}} \theta_{\mathrm{ij}}, \lambda_{\mathrm{i}}{ }^{*}=\Sigma_{\mathrm{j}=0}{ }^{\mathrm{ki}} \lambda_{\mathrm{ij}} ; \mathrm{n}=1,2, \ldots, 23 ; \mathrm{t}=1995,1996, \ldots, 2009$.

Panel ARDL results were calculated by Stata 10 and the results are shown in Table 3.

The findings of the study show that capital formation per capita and index of globalization have positive effect on transition countries.

Animal and vegetable oils, fats and waxes; commodities and transactions, n.e.s; mineral fuels, lubricants and related materials; food and live animals were found to have positive effects on economic growth. Only the coefficient sign of the animal and vegetable oils, fats and waxes were statistically significant. Beverages and tobacco; chemicals and related products, n.e.s.; crude materials, inedible, except fuels; manufactured goods; machinery and transport equipment; miscellaneous manufactured articles had negative effects on the economic growth of transition countries. The coefficients of beverages and tobacco; chemicals and related products, n.e.s.; crude materials, inedible, except fuels; manufactured goods were statistically significant. 
Table 3. Panel ARDL model estimation results (pooled mean group or mean group)

\begin{tabular}{|c|c|c|c|c|c|c|c|c|c|c|}
\hline \multicolumn{11}{|c|}{ Dependant Variable: LGDPPC } \\
\hline \multicolumn{11}{|c|}{ Coefficients and $p$ values } \\
\hline & ANIM & BEVE & CHEM & CRUDE & $\mathrm{COM}$ & MAN & $\mathrm{MACH}$ & MIN & MISC & FOOD \\
\hline \multirow[t]{2}{*}{ BALASSA } & $0.039^{\mathrm{A}}$ & $-0.069^{A}$ & $-0.335^{\mathrm{A}}$ & $-0.017^{\mathrm{A}}$ & 0.0006 & $-0.359^{\mathrm{A}}$ & -0.023 & 0.075 & -0.160 & 0.230 \\
\hline & $(3.06)$ & $(-2.84)$ & $(-5.23)$ & $(-8.38)$ & $(0.47)$ & $(-5.57)$ & $(-0.34)$ & $(0.72)$ & $(-0.43)$ & $(0.97)$ \\
\hline \multirow[t]{2}{*}{ LCAPPC } & $0.436^{\mathrm{A}}$ & $0.504^{\mathrm{A}}$ & $0.227^{\mathrm{A}}$ & $0.446^{\mathrm{A}}$ & $0.381^{\mathrm{A}}$ & $0.450^{\mathrm{A}}$ & $0.462^{\mathrm{A}}$ & $0.660^{\mathrm{B}}$ & $0.398^{\mathrm{B}}$ & $0.392^{\mathrm{B}}$ \\
\hline & $(47.69)$ & $(10.93)$ & $(15.66)$ & $(35.97)$ & (13.43) & $(16.23)$ & $(11.22)$ & $(2.04)$ & $(2.04)$ & $(2.12)$ \\
\hline \multirow[t]{2}{*}{ LKOF } & $0.857^{\mathrm{A}}$ & $1.404^{\mathrm{A}}$ & $0.982^{\mathrm{A}}$ & $0.548^{\mathrm{A}}$ & $2.538^{\mathrm{A}}$ & $1.153^{\mathrm{A}}$ & $1.598^{\mathrm{A}}$ & -0.220 & 0.473 & 0.637 \\
\hline & $(16.54)$ & $(9.73)$ & $(13.76)$ & $(6.39)$ & $(15.87)$ & $(6.56)$ & $(8.14)$ & $(-0.23)$ & $(0.79)$ & $(0.80)$ \\
\hline \multirow[t]{2}{*}{$\mathrm{EC}$} & $-0.150^{\mathrm{A}}$ & $-0.111^{\mathrm{A}}$ & $-0.161^{\mathrm{A}}$ & $-0.203^{\mathrm{A}}$ & -0.026 & $-0.120^{\mathrm{A}}$ & $-0.126^{\mathrm{A}}$ & $-0.382^{\mathrm{A}}$ & $-0.402^{\mathrm{A}}$ & $-0.382^{\mathrm{A}}$ \\
\hline & $(-3.81)$ & $(-3.79)$ & $(3.20)$ & $(-4.50)$ & $(-0.60)$ & $(-4.43)$ & $(-4.27)$ & $(-6.26)$ & $(-5.47)$ & $(-8.75)$ \\
\hline \multirow[t]{2}{*}{ DBALASSA } & -0.529 & -0.084 & 0.036 & -0.064 & 0.007 & -0.0161 & 0.014 & -0.0504 & 0.025 & -0.002 \\
\hline & $(-0.85)$ & $(-0.8)$ & $(0.63)$ & $(-0.96)$ & $(0.66)$ & $(-0.98)$ & $(0.40)$ & $(-1.63)$ & $(0.45)$ & $(-0.05)$ \\
\hline \multirow[t]{2}{*}{ DLCAPPC } & $0.134^{\mathrm{A}}$ & $0.161^{\mathrm{A}}$ & $0.147^{\mathrm{A}}$ & $0.128^{\mathrm{A}}$ & $0.200^{\mathrm{A}}$ & $0.147^{\mathrm{A}}$ & $0.138^{\mathrm{A}}$ & $0.048^{\mathrm{A}}$ & $0.0871^{\mathrm{A}}$ & $0.068^{\mathrm{A}}$ \\
\hline & $(5.08)$ & $(6.12)$ & $(6.11)$ & $(4.60)$ & $(6.73)$ & $(5.85)$ & $(5.16)$ & $(2.40)$ & $(3.38)$ & $(3.33)$ \\
\hline \multirow[t]{2}{*}{ DLKOF } & $0.134^{\mathrm{A}}$ & 0.021 & $-0.194^{\mathrm{A}}$ & -0.117 & 0.089 & 0.006 & -0.040 & -0.032 & -0.075 & $-0.125^{\mathrm{B}}$ \\
\hline & $(-0.97)$ & $(0.25)$ & $(3.65)$ & $(-1.34)$ & $(0.94)$ & $(0.08)$ & $(-0.52)$ & $(-0.36)$ & $(-0.67)$ & $(-2.01)$ \\
\hline \multirow[t]{2}{*}{ CONS } & $0.181^{\mathrm{A}}$ & $-0.141^{\mathrm{A}}$ & $-0.194^{\mathrm{A}}$ & $0.492^{\mathrm{A}}$ & -0.114 & $0.0583^{\mathrm{A}}$ & $-0.227^{\mathrm{A}}$ & $0.625^{\mathrm{B}}$ & $0.880^{\mathrm{C}}$ & $0.767^{\mathrm{B}}$ \\
\hline & $(4.43)$ & $(-3.08)$ & $(3.83)$ & $(4.64)$ & $(-0.49)$ & $(4.98)$ & $(-3.76)$ & $(2.01)$ & (1.67) & $(2.21)$ \\
\hline \multirow[t]{3}{*}{ Hausman Stat. } & 1.66 & 0.79 & 1.69 & 0.83 & 1.71 & 3.73 & 2.08 & 39.62 & NA & 10.16 \\
\hline & $(0.644)$ & $(0.850)$ & $(0.639)$ & $(0.842)$ & $(0.634)$ & $(0.292)$ & $(0.556)$ & $(0.00)$ & & $(0.017)$ \\
\hline & PMG & PMG & PMG & PMG & PMG & PMG & PMG & MG & MG & MG \\
\hline
\end{tabular}

Notes: D is first difference operator. C, B and A are level of significance at 10, 5 and 1 percent levels of significance, respectively. $t$ values are given in the parenthesis. Prop. values are given in parenthesis for Hausman statistics. PMG means pooled mean group, MG means mean group and EC means error correction coefficient.

\section{Conclusion}

Following the collapse of the Soviet Union, transition countries have introduced market-oriented economies. Following the structural changes from socialist and closed-market systems to open markets, transition economies are showing rapid growth that averages five percent of GDP per capita since 1996. The findings of the study show that globalization has a positive effect on transition countries. It was almost found statistically significant coefficients for the KOF indexes for every selected industry and sub-branch of industries. In addition, some industrial sectors and sub-sectors are positively associated with the economic growth of transition countries while some of them are negatively associated.

\section{References}

Anderson, L., Ola, G., \& Lars, L. (2000). Structural Change, Competition and Job Turnover in Swedish Manufacturing Industry 1964-96. Review of International Economics, 8, 566-582. http://dx.doi.org/10.1111/1467-9396.00242

Balassa, B. (1965). Trade Liberalization and Revealed Comparative Advantage. Manchester School of Economic and Social Studies, 33, 99-123. http://dx.doi.org/10.1111/j.1467-9957.1965.tb00050.x

Business Council of Australia. (2008). Improving International Competitiveness in Australian Business, Melbourne.

Demir, İ. (2001). The Competitiveness and Future of the Durable Goods in Turkey. The State Planning Organization, expertise dissertation, No. 2571, Ankara.

Dollar, D., \& Kraay, A. (2002). Growth is good for the poor. Journal of economic growth, 7, 195-225. http://dx.doi.org/10.1023/A:1020139631000

Fagerberger, J. (1996). Technology and Competitiveness. Oxford Review of Economic Policy, 12(3), 39-51. http://dx.doi.org/10.1093/oxrep/12.3.39

Farrugia, N. (2002). Index of International Competitiveness for Malta. FarrBugainak of Valletta Review, 26, 20-37.

Fischer, S., \& Ranta, S. (2004). Transition Economies: The Role of Institutions and Initial Conditions. IMF 
mimeo. Washington D.C.

Fischer, S., Ratna, S., \& Carlos, A. V. (1996). Stabilization and Growth in Transition Economies: The Early Experience. Journal of Economic Perspectives, 10, 45-66. http://dx.doi.org/10.1257/jep.10.2.45

Kaldor, N. (1981). Essays on value and distribution. New York: Holmes \& Meier Publishers.

Lafay, G. (1992). The Measurement of Revealed Comparative Advantage. In M. G. Dagenais \& P. A. Muet (Eds.), International Trade Modelling. London: Chapman \& Hall.

Liesner, H. H. (1958). The European Common Market and British Industry. Economic Journal. http://dx.doi.org/10.2307/2227597

Nowak-Lehmann, D. F., Vollmer, S., \& Martinez-Zarzoso, I. (2008). Does Comparative Advantage Make Countries Competitive? A Comparison of China and Mexico. Georg-August-University, Goettingen.

Peseran, H. (2006). A simple panel unit root test in the presence of cross section dependence. Cambridge University, Working paper, no: 0346.

Peseran, M. H., Shin, Y., \& Smith, R. J. (1999). Pooled mean group estimation of dynamic heterogeneous panels. Journal of the American Statistic Assosiation, 94, 621-634. http://dx.doi.org/10.1080/01621459.1999.10474156

Porter, M. E., \& Victor, E. M. (1985). How Information Gives You Competitive Advantage. Harward Business Review, July-August, 1-13.

Salvatore, D. (2010). Globalisation, International Competitiveness and Growth: Advanced and Emerging Markets, Large and Small Countries. Journal of International Commerce, Economics and Policy, 1(1), 21-32. http://dx.doi.org/10.1142/S179399331000007X

Sener, S., \& Saridogan, E. (2011). The Effects Of Science-Technology-Innovation On Competitiveness And Economic Growth. Procedia Social and Behavioral Sciences, 24, 815-828. http://dx.doi.org/10.1016/j.sbspro.2011.09.127

Smith, S. (1995). World-class Competitiveness. Managing Service Quality, 5(5), 36-42. http://dx.doi.org/10.1108/09604529510100387

Soete, L. (1981). A General Test of the Technology Gap Trade Theory. Weltwirtschaftliches Archiv, 117(4), 638-656. http://dx.doi.org/10.1007/BF02708115

Thirlwall, A. P. (1979). The Balance of Payments Constraint as an Explanation of International Growth Rate Differences. Banca Nazionale del Lavoro Quarterly Review.

Ulengin, F., Kabak, Ö., Onsel, S., Aktas, E., \& Parker, B. R. (2011). Competitiveness of nations and implications for human development. Socio-Economic Planning Science, 45, 16-27. http://dx.doi.org/10.1016/j.seps.2010.10.001 